\title{
Who is a Refugee? Understanding the Figure of the Refugee against the Backdrop of the Bengal Partition (1947-1970)
}

\author{
Sumallya Mukhopadhyay \\ Doctoral Fellow and Teaching Assistant, Department of Humanities and Social Sciences, \\ Indian Institute of Technology Delhi, New Delhi. ORCID ID: oooo-0oo2-4762-2099 \\ Email: mukhopadhyay.sumallya@gmail.com,
}

\begin{abstract}
The paper intends to study the figure of the refugee in post-Partition West Bengal by critically examining the oral history narratives of individuals who migrated from East Pakistan in the wake of the 1947 Partition. It underscores the value and relevance of narrativity in the representation of factual history, the motivation and manifestation of which make history subjective, interpretive and contingent on the refugee's narrative. The narrative act presents the refugees' transition from, what may be called, figurative to socio-material subjects who interrupt and derange the nationalising exercise of the nation-state. The multivalent understanding of refugees makes the nation-state suffer from an anxiety of incompleteness (Appadurai 2006). The paper extends the idea of incompleteness by showing that however much the nation-state attempts to frame a particular brand of nationalism, variants of ethnocultural nationalism do exist, demonstrating the diverse subjectivities embodied by the refugees/narrators. Such ethnocultural nationalism can be read as alternative forms of self-assertion deeply etched in the social memory of the refugees.
\end{abstract}

Keywords: Partition, Bengal, Refugees, Migration, Narratives, Ethnocultural

\section{Introduction}

In his essay, 'The Death of an Empire', Ashis Nandy remarks:

"The 1940s introduced into the South Asian public life a new actor-the refugee. He was uprooted, partly deracinated, embittered victim who knew suffering and had seen the transience of social ties, betrayal of friends and the worst of human depravity-his own and that of others. Politics in South Asia would never be the same again" (2002, p. 11).

In their effort to get rid of the yoke of colonial subjugation, nationalists from every quarter of the political spectrum acceded to the 1947 Partition plan that coincided with the Independence of South Asia (Ghoshal 2021, p. 22-24). One understands that the liberation from the Raj, as Nandy puts it, 'did not come as a single, identifiable event in 1947'; instead, the historically significant process of dismantling the Raj began with the Great Calcutta riots in 1946, culminating in the genocide in Punjab (Nandy 2002, p. 5). The drastic change in the geographical contours resulted in unspeakable anxiety and disorder, psychologically affecting individuals who suddenly found themselves on the wrong side of the Radcliffe Line (Jain and Sarin 2018, p. 6). In the process, they were forced to disclaim their ancestral hearth and home in search of a safe space where they had to start their life anew.

Against the backdrop of the 1947 Partition $^{\text {ii }}$, the paper explores the figure of the refugee who migrated from East Pakistan to West Bengal between 1947 and 1970. The first section of the paper

(c) AesthetixMS 2021. This Open Access article is published under a Creative Commons Attribution Non-Commercial 4.0 International License (http://creativecommons.org/licenses/by-nc/4.o/), which permits non-commercial re-use, distribution, and reproduction in any medium, provided the original work is properly cited. For citation use the DOI. For commercial re-use, please contact editor@rupkatha.com. 
concentrates on the moment of the rupture in 1947 and the ensuing refugee crisis in West Bengal. It argues that the unabated movement of individuals - for some two decades after the Partitionpositioned the 'refugee' as a distinct social category in West Bengal. The second section advances this categorization by studying the oral history narratives of the refugees, classifying them as figurative and socio-material subjects where they emerge as agentive, desiring and enterprising individuals. In the last section, the paper highlights the ethnocultural distinctiveness of the refugees. It concludes by foregrounding that though the nation-state might aspire to indoctrinate a particular brand of nationalism, variants of ethnocultural identity exist which do not entirely operate on the basis of cartographic borders. Such ethnocultural distinctiveness can be read as alternative forms of self-assertion inculcated in the social memory of the refugees. ${ }^{\mathrm{iii}}$

\section{The Moment of Rupture and Refugee Crisis}

In August 1947, the moment of rupture was so sudden and chaotic that even before individuals and their families could make sense of the situation, most of them had to start migrating. ${ }^{\text {iv }}$ Though Calcutta was the epicentre of the first riots that led to the Partition, violence soon erupted in other parts of the country, stretching from Bihar, United Provinces (present-day Uttar Pradesh), Bombay, Delhi and Punjab. Yasmin Khan writes that a web of fear pervaded among the Hindus and the Muslims who engaged in ruthless killing of each other. The riots, she opines, were politically provoked as news of violence spread through 'rumours' (2017, 70-85). In fact, Punjab wallowed in an orgy of reciprocal violence, the most appalling exposition of which could be cited as trains, packed with refugees, were attacked. Compared to Punjab, the situation in West Bengal was not so grave, but a sense of insecurity and loss persuaded many to leave their ancestral land (Chatterji 2019, p. 97-99). That one's home fell on the wrong side of the Radcliffe Line was reason enough to cross the borders; otherwise, oppression, exploitation, even religious conversion and death were the destined lot. Joya Chatterji delineated the pattern of movement to showcase that in both sides of truncated Bengal, those who had property and land were the first to migrate (2007, p. 112-113). Nonetheless, the cross-border migration from East Pakistan to West Bengal was not restricted to years immediately following the Partition. The fluctuation in India-Pakistan diplomatic relationship, introduction of passport, full-scale war between the two nations, anti-Muslim violence in West Bengal and anti-Hindu riots in East Pakistan directed the ebb and flow of refugee migration (Mukhopadhyay 2021, p. 136).

In official parlance, the idea of refugee did not 'coincide with either that of the migrants or that of the displaced. Since these terms [were] are not mutually exclusive, the government sometimes used them freely without making any distinction between them' (Das 2003, p. 107). Though the term 'displaced persons' had gained currency in bureaucratic paperwork, individuals fleeing from East Pakistan were also called evacuees in the late 1940s and early 1950s (Ghoshal 2021, p. 57). At times, the refugees were also called 'migrants' who crossed over to West Bengal to eke out a living for themselves after having faced a harsh work environment in East Pakistan. The agriculturalists migrating from Khulna, East Pakistan to West Bengal in 1951 following a period of drought is a point to reckon with (Bandyopadhyay 1960, p. 168). It must be borne in mind that the Partition along the communally demarcated borders necessarily meant that refugees would rather be naturally assimilated with the host country's population as they were of the same religious ilk and clan. Yet, ironically, one had to embrace the status of a refugee in order to claim the right to rehabilitation from the nation-state. In other words, the 'refugees who sought shelter in India and Pakistan in the aftermath of partition claimed to be both refugees and citizens of their putative homelands' (Sen 2018, p. 3). 
A simplistic understanding of cross-border migration is about the movement of individuals, but when people move from one region to another, they carry with them their cultural mores, societal dynamics and linguistic affinities (Ferris and Kirişci 2016, p. 35; Krause and Schmidt 2020, p. 24). Such multivalent and multi-layered comprehension of a refugee questions the grounds of assimilation based solely on religious background. The expanding presence of the refugees provides a scope to read them as a social category. The formation of refugees as a social category is symptomatic of the problems a refugee poses to the host nation. It points to the politics of hospitality', which is a constant negotiation between the absolute terms prescribed by the nationstate and the relative, liminal presence of the refugees who inhabit spaces in between geographies and nationalities (Samaddar 2003, p. 28).

\section{Refugees as Figurative and Socio-Material Subjects}

Inducted as mere numbers and figures in the official records, the refugees, for the most part, were classified as, what may be termed, figurative subjects. When news of communal riots and subsequent migration came to surface, the official reports and documents registered them as nameless numbers. The numbers were an uncomfortable reminder for the nation-state of its failure to tackle the refugee problem in West Bengal. The Union Minister of Rehabilitation (1948-1950), Mohanlal Saksena presided over a meeting in the Writers' Building, West Bengal in 1949. He proposed that refugees in West Bengal would not be given rehabilitation, but temporary shelter, and the government would urge the refugees to return to their home in East Pakistan. ${ }^{\mathrm{v}}$ Following February 1950, the refugees were discouraged to stay in the camps. Few had relatives and could end up with them (Chatterji 2007, p. 123). But most of the refugees did not have necessary resources to procure land for themselves. Though a substantial portion of them needed institutional support, they were denied necessary aid. Instead, they were left to fend for themselves in camps. Manoranjan Byapari, who migrated from East Pakistan in 1953, writes in his autobiography:

"We spent quite a few days in Sealdah Station platform after arriving in [West] Bengal. From there we were taken to Shiromanipur Camp in Bankura District...The government godowns (sic.) from where we would collect our usual dole of rice possibly possessed very old stock...Everyone suffered from stomach disorders for the first few days as a consequence of eating the rice. There was no lavatory within the camp...At this time when people were dying like flocks of chickens what was the benevolent government doing?" (2018, p. 17).

The miserable plight of the refugee camps forced the nation-state to take cognizance of its inconsistencies when it came to forging a nation after 1947. The need of the hour was to make the refugees invisible by transferring the inhabitants of the camps to Central India, Andaman Islands and neighbouring regions of West Bengal. ${ }^{\text {vi }}$ After migrating from East Pakistan in 1955, Bhadro Biswas stayed at a refugee camp in Hasnabad for a few weeks. He was soon transferred to another camp in Central India. He said, "From the [Hasnabad] refugee camp, the government officials put us in trucks and shifted us to the Mana camp in Raipur, Chhattisgarh."vii The officials in West Bengal served repeated notices to the refugees, imploring them to move out of the camps. ${ }^{\text {viii }}$ The disinclination of the refugees to leave the camps irritated the government officials. ${ }^{\text {ix }}$ Interestingly, the stories of the refugees' resilience and grit are couched within the history of their dependence on institutional support and the nation-state's apathetic responses to the crisis. In the course of time, one witnesses how the refugees reorient themselves as products of their social and material conditions.

The methodology of oral history which consists in the act of narrating one's experiences offers the refugees an opportunity to articulate their subjective understanding of the historical 
event. Adam Wiesner observes that oral history encourages the interviewees to recollect, and 'the primary goal is to construct knowledge' from the vantage point of those who have been elided from standard historiography (2021, p. 101). The framing of the past events helps in historical reconstruction that deviates from the 'traditional State-sanctioned history' ( $\mathrm{Na} \mathrm{Li} \mathrm{2020,} \mathrm{p.} \mathrm{26).} \mathrm{As}$ the oral narrative moves away from factual rendering to a more personalised account of the happening, it opens up a 'narrative space' that allows the refugees to lay stress on their version of the history (Portelli 2018, p. 243). In 'The Question of Narrative in Contemporary Historical Theory', Hayden White expounds a form of history that narrates and narrativizes, letting a story unfold itself. He puts forward the view that narrativizing differentiates history from chronicles and annals wherein history becomes textually mediated in its endeavour to represent and interpret facts (1984, p.2). The introduction of narrative as a method to construe factual history invests historical representation with tangible perspective and subjectivity, essentially blurring the distinction between storytelling and historiography, narrative and history (Kabir 2013, p. 11; Gera Roy 2020, p. 67). Here, a narrative's truth-value or informational content is replaced by comprehending it as a complex set of codes, engendered by the narrator's own subjectivity (Portelli 1991, p. 50). The oral narratives facilitate the categorisation of the socio-material subject which acts as a theoretical extension where it follows the figurative refugee-configured in official records as faceless numbers-who assertively evolves to counter the shifting phases of being a sufferer of circumstances and a powerless individual before the nation-state. In the popular memory of the Partition in West Bengal, the refugees are conceptualised in two stances-the victim or the victor, the powerless or the powerful. ${ }^{x}$ The paper argues that the refugees in West Bengal do not always remain poised between these two subject-positions. Their narratives move beyond the binary to point to the socio-material categorisation which is conditioned by the circumstances that the refugees have encountered in their lives. For one thing, the refugees make their presence felt as agentive, enterprising and participatory individuals; they take chances, create possibilities, being, at the same time, aware of the situations that might suppress and marginalise their individuated perceptions.

Manoranjan Mondal was forced to relinquish his home in 1970 as the Pakistani army stormed into his village. He migrated to West Bengal, and from the border check-post, he was taken to Kurud camp in Raipur. He remembers how he started his own business after being transferred to the camp. ${ }^{\text {xi } ~ " T h e ~ l a n d ~[i n ~ K u r u d] ~ t h a t ~ w a s ~ o f f e r e d ~ t o ~ u s ~ c o u l d ~ n o t ~ b e ~ c u l t i v a t e d, ~ s o ~ I ~ d e c i d e d ~ t o ~}$ try my hand in business", said Manoranjan Mondal. He started trading kerosene oil and garments, somehow managing to make both ends meet. The authorities of the camp wanted him to stop the business. It points to the fact that personal initiatives to be financially independent were not encouraged by camp authorities. On being questioned, he said, "The camp officials wanted us to clear the forest area, but we were paid so little that I did not want to be dependent on them." In the official scheme of things, it appeared that refugees were to perform designated jobs (Ghoshal 2021, p. 110). Denying autonomy and agency to the refugees through inimical camp-based policies constricted their aspirations for social mobility (Mukhopadhyay 2019, p. 124). Manoranjan Mondal, however, challenged these policies and went to Delhi and sought permission to continue with his business. In another such interview, Sukhen Howladar, who migrated in 1950, talks about the shop he had built at Kashipur camp in Burdwan. ${ }^{\text {xii }}$ From Sealdah railway station, his family was taken to the camp at Kashipur. He said, "We were given a dole of three rupees per family member. It was not enough to sustain my family. I figured that camp residents needed essential items like soap, puffed rice, oil etc. I obtained the items from the Burdwan town and set-up a shop." Sukhen Howladar and his family were not permanently rehabilitated at Kashipur. After two years, the family was again shifted and taken to Dhubulia camp. On being asked if this hampered his business, 
he replied, "I did not invest much on the structure of the shop. So, I barely faced any loss. On reaching Dhubulia, I re-started my shop. The camp in Dhubulia had more refugees, so the business was better here." Santi Ranjan Banerjee migrated along with his siblings in the months leading to the Partition. ${ }^{\text {xii }}$ Initially, his family found refuge in a camp at Ballygunj Circular Road, Kolkata. The precarity and difficulty of living in a camp deeply tormented the residents. They planned to create an identity of their own to collectively address their concerns. Santi Ranjan Banerjee narrated, "The area of the camp was marked out by fences. It created an impression that our locality was different from the surrounding neighbourhoods. By forming a club, we wanted to convey to our neighbours that we were not different from them, but the situation we found ourselves in was different." The club 'Sangha Shree' was founded in 1949. It acted as a congenial space where the camp residents would gather to interact and share their daily experiences. Santi Ranjan Banerjee continued, "Most of us struggled to find work in Kolkata. The city was so burdened with refugees that few entertained our applications. Every evening, the seniors of the family would meet in the club and inspire each other to keep trying. Some of us gradually could find jobs. The club was also used as a primary school for the children in the camp." Within a few years, the government asked the residents to vacate the camp at Ballygunj because it had to be used to shelter the newly arrived refugees from East Pakistan. The leaders of the camp identified some unused lands in the south of Kolkata near Bansdroni, and they decided to occupy the area. Interestingly, the club was also shifted to the new locality that they had inhabited.

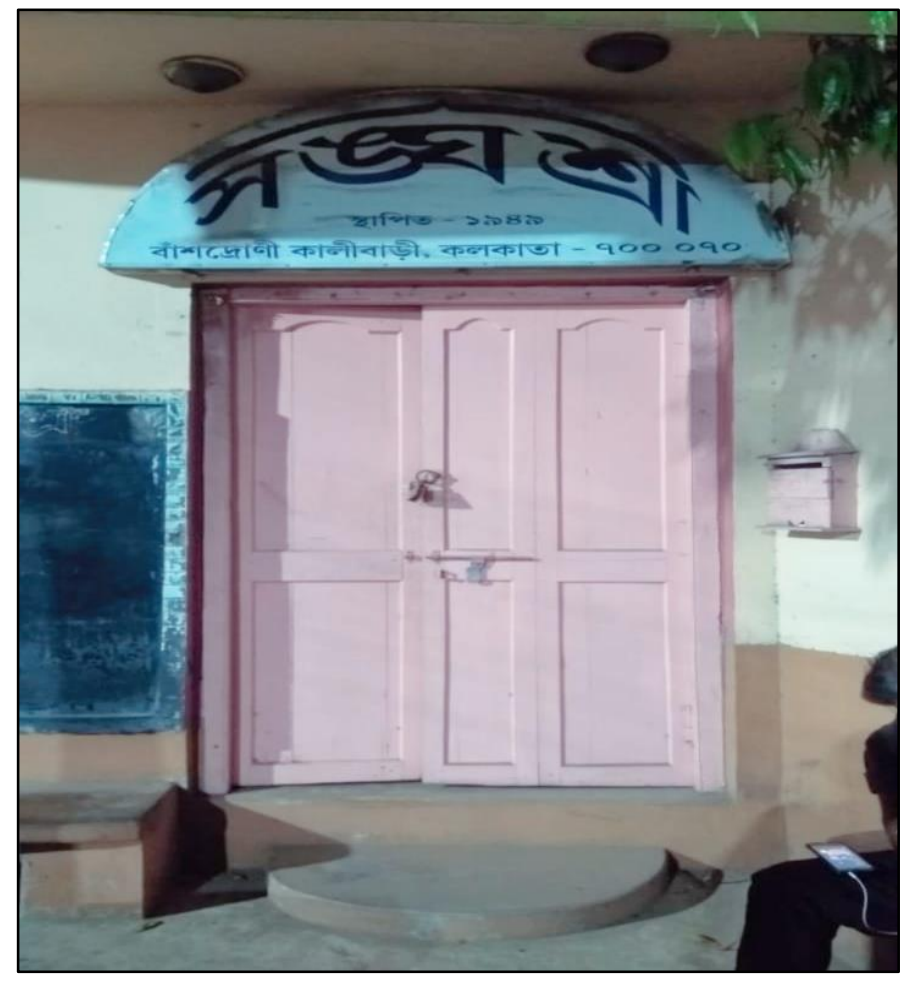

Figure 1: Founded in 1949, 'Sangha Shree' as it exists today in Bansdroni, Kolkata (photo: author)

Though the refugees moved to the new area in 1954, the foundation year of the club was kept as 1949. Santi Ranjan Banerjee said, "We intentionally kept it as 1949, even after shifting to Bansdroni. 
We helped each other to find a footing in the city. The club symbolised the sense of togetherness of the refugees."

Debabrata Dutta migrated with his parents, two sisters and younger brother in $1947 \cdot{ }^{\text {xiv }} \mathrm{He}$ reminiscences how his father, Santhosh Kumar Dutta, founded the Bijoygarh Colony near Jadavpur, Kolkata. "It was a jabardakal (forcefully occupied) colony. My father and few others found few desolated army barracks near Tollygunj, Kolkata. They occupied the barracks and the neighbouring areas, and they distributed them to various families who came from East Pakistan. We kept handing the vacant lands to refugees for some ten years after the Partition", said he. To substantiate his point, he referred to a letter that his father received from one of his acquaintances in 1958 who requested Santhosh Kumar Dutta to give shelter to an abandoned woman in the refugee colony.

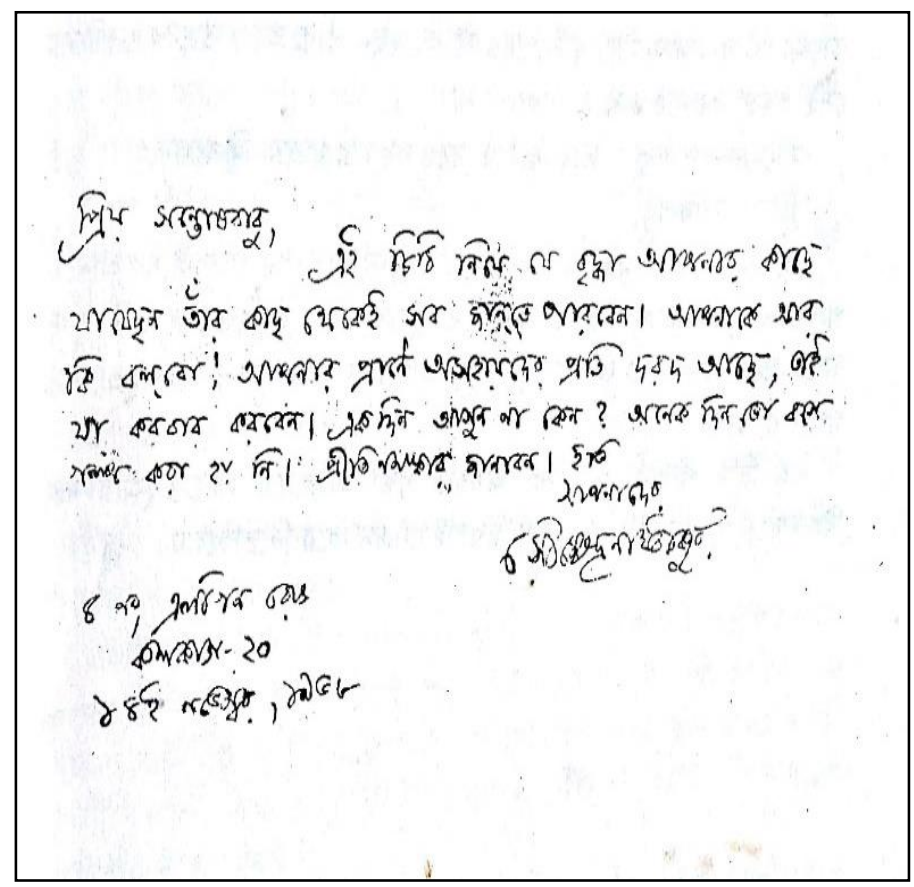

Figure 2: The letter that Debabrata Dutta's father received, dated 14 November 1958 (photo: author)

Pabitra Bhusan Bhattacharya, who migrated in 1948 and came to, what is at present called Bidhan Pally in Kolkata, said, "We forcefully occupied a vacant area." ${ }^{x v}$ For a considerable period of time, his family stayed in a makeshift hut. The area belonged to a rich landlord whose hired goons would come and demolish the settlement. At night, the refugees would again re-build their huts. Pabitra Bhusan Bhattacharya recollected, "The landlord realised that we would not leave the place. Reluctantly, he gave up and stopped visiting the area. But having a roof on our heads did not materialise into having food on our plates. On most nights, my family slept empty stomach."

The narratives of Manoranjan Mondal, Sukhen Howladar, Santi Ranjan Banerjee, Debabrata Dutta and Pabitra Bhusan Bhattacharya evince that the refugees, inducted as figures and numbers, emerged as socio-material subjects who intermittently adapted themselves to the prevailing circumstances to fashion a semblance of normal life. One of the methods the refugees adopted was to assert and highlight their ethnocultural identity. 


\section{The Ethnocultural Identity of the Refugees}

The socio-material refugee subjects are not merely a collective presence; they nurture a definite political viewpoint. They give stress on a distinct ethnocultural identity which they want the nationstate to recognise and acknowledge, and on the basis of it, the refugees derive certain cultural and political rights. Most importantly, their emphasis on a public claim to membership in a country different from the dominant cultural and political community, orientates them in a manner that is beyond the victim-victor binary. It creates a framework where their identities get mapped, negotiated and contested. The political underpinnings of the Partition focus on the need to protect the religious minority, namely, the Muslims in South Asia from being subservient to the majority Hindus; the idea of a nation, with a religious minority within its territorial and spatial domain, eventually coincides with the formation of socio-material refugee subjects who, owing to their cross-border ethnocultural identity, are strategically occluded from the nationalising process of the nation-state. ${ }^{\text {xvi }}$ The situation in West Bengal is not unique. In West Pakistan, especially in the Sindh province-Karachi, Hyderabad, Mirpurkhas and Sukkur - the Muslim refugees from India are called the Mohajirs - a distinct ethnic group that is 'linguistically, culturally, politically, socially and economically' different from the Sindhi inhabitants of the host country (Zaidi 1991, p. 1295). In The Politics of Refugees in South Asia, Navine Murshid explains that the 'Muslims from India who migrated to Pakistan are called "Muhajir" in Pakistan; Bangalis from Muslim parts of Bengal (East Bengal, now Bangladesh) who migrated to India are called "Bangal"' (2013, p. 14). One understands that like the Mohajirs in West Pakistan, the Hindu refugees from East Pakistan are called Bangals as distinct from the Ghotis settled in West Bengal though such essentialization predates the Partition. "To the people of West Bengal”, Byapari believes, “The words 'refugee' and 'Bangal' are synonymous. And the word 'Bangal', a name for the people from East Bengal, was also, for all practical purposes, a word of abuse too...In the eyes of the Ghoti of West Bengal, the Bangal is always an outsider" (2018, p. 41) [emphasis mine]. Living in a kind of social anxiety and trepidation, the Ghoti community had always tried to portray their Bangal counterparts as culturally, linguistically and socially inferior to them (Sarkar 2010, 158-159). On account of the Partition, the dynamics of the Ghoti-Bangal relationship reconfigured itself insomuch that Prasanta Kumar Chatterjee, in his interview, said, "To be a refugee is, of course, linked with my Bangal identity. I am proud of my Bangal identity. It also means I am a refugee. I am proud of being a refugee as well." ${ }^{\text {vvii }}$ Quite significantly, Mahesh Das used the terms 'Bangal' and 'refugee' simultaneously. After crossing the borders to reach West Bengal, his family along with others built a settlement near Bangaon and named it Sitanathpur village. He said, "We are all Bangals here who reside in this refugee settlement. We also refer to it as the Bangal neighbourhood, for, after all, we are all refugees and Bangals."xviii

While deliberating on the ways nationalism generated nations, Ernest Gellner posits that a well-maintained and centralised education system is an integral component for the nation-state to preach and promote its brand of nationalism (1983, p. 65). For the Bangal refugees in West Bengal, education appeared as a crucial tool through which they could strive not only for social mobility, but also be aware of their rights and claims. Here, the socio-material aspect of the refugee attains its apogee, especially because it yearns for a more active participation in the society. Manas Ray is of the opinion that "Shiksha [Bengali word for education] would help us [the refugees] win recognition from Calcutta...something we thought we rightfully deserved but were deprived of" (Ray 2001, p. 134). Nilima Kundu candidly admits that she took education seriously because she did not want to be dependent on anyone. "I did not want to be a liability to my brother-in-law who 
stayed in Dum Dum. I finished my education, secured a job as a principal in a primary school and used to cover all expenses myself."xix

In the time of forced displacement or rapid migration, the host nation is tormented with uncertainty over the presence of the outsider within its territorial domain (Appadurai 2006, p. 5). While the host nation intends to homogenise the populace, the agonising proximity of the abandoned homeland and the simultaneous cultural difference with the host population produce precarious subjectivities among the refugees. The failure to indoctrinate the idea of one national collective makes the nation-state suffer from, what Arjun Appadurai deems, an anxiety of incompleteness (2006, p. 8). The partition of Bengal borders entails the question of identity as its natural corollary. It has been emphasised time and again that the refugees needed to prove their citizenship credentials. As a matter of fact, documentation is an integral part of the refugee crisis so much so that it becomes a perpetual liability for the refugees to prove their identity. While talking about the documents that he has preserved, Santosh Kumar Biswas mentioned: "I used to receive refugee stipend because of a document. It is the certificate of registration. Despite the wear and tear, I have somehow managed to keep it with me because I believe that it will come in handy someday." xx

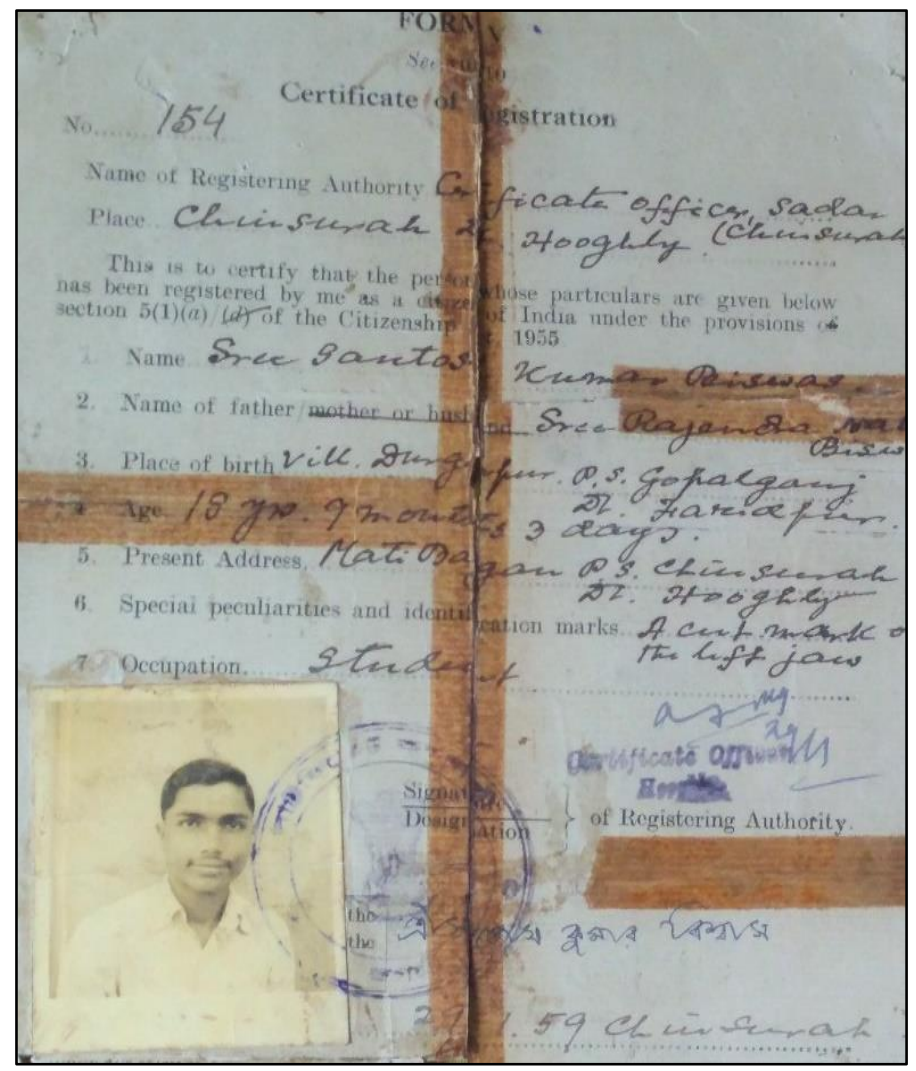

Figure 3: The Certificate of Registration of Santosh Kumar Biswas (photo: author)

This fear to prove one's belongingness to a country where one was supposed to be naturally assimilated, points to the discrepancies in the unitary, national narrative. In a sense, the refugees emerge as the social category in opposition to those who hold socio-economic power owing to their consolidated presence in the host nation. 


\section{Conclusion}

According to Appadurai, identities do not become majoritarian only by large numbers; certain identities appear to have majoritarian tendencies and predatory instincts when they strive to close the gap between the majority and the purity of the national whole (Appadurai 2006, p. 52). On the one hand, the inhabitants of the host nation-majoritarian, so to speak, not in the sense of large numbers but by their consolidated presence-define the position of the refugees in the societal hierarchy. On the other hand, the cultural configuration and ideological framework of the ethnocultural distinctiveness of the refugees open up a field of competitive subjectivities and stances. Most importantly, it helps us understand that however much the nation-state might desire to promote a particular brand of nationalism (Gellner 1983, p. 55), variants of ethnocultural identity firmly exist, and they can be read as alternative forms of self-assertion ingrained in the social memory of the refugees.

\section{Acknowledgements}

By virtue of a research grant, the author had access to the 1947 Partition Archive's repository of oral history interviews. The author would like to thank the members of the archive for their help. The arguments of the paper, however, are the author's own and in no way reflect the views of the 1947 Partition Archive. An abridged version of this paper was presented as a special lecture in the Fourth Orientation Course on Migration, Tata Institute of Social Sciences, Patna in February 2020.

\section{Endnote}

\footnotetext{
i The cartographic borders between Pakistan, India and Bangladesh (formerly, East Pakistan) are called the Radcliffe Line, named after Cyril Radcliffe, the joint commissioner of the Boundary Commission.

ii Hereafter referred to as the Partition

iii It must be noted that throughout the paper, the author uses the terms 'refugee' and 'narrator' interchangeably.

iv See Yasmin Khan's 'Introduction: The Plan' in The Great Partition: The Making of India and Pakistan, $2^{\text {nd }}$ ed., 2017, p. 1-10

${ }^{v}$ File No. 4M-12/51, B. June 1954 148-154, West Bengal State Archives, Kolkata, West Bengal

${ }^{v i} 16$ July 1959 Amrita Bazar Patrika, Nehru Memorial Museum and Library (henceforth, referred to as ABP and NMML respectively)

vii Bhadro Biswas interviewed by the author on $28^{\text {th }}$ June 2018; the interviews are conducted in Bangla. The author has taken the liberty to translate them.

viii 7 January $1961 A B P$, NMML

ix 18 March $1961 A B P$, NMML

x Prafulla K. Chakrabarti's The Marginal Men (1990), Jasodhara Bagchi, Subhoranjan Dasgupta \& Subhasri Ghosh's edited The Trauma and The Triumph (vol. I-II) (2003 \& 2009), Manas Ray's 'Growing Up Refugee' (2002) and Debali Mookerjea-Leonard's Literature, Gender \& The Trauma of Partition (2017) have conceptualised the refugees from East Pakistan as either hapless victims of circumstances or victors who overcame the predicaments that they had faced. Uditi Sen provides a critique of this binary position in her book Citizen Refugee (2018). In The Refugee Woman (2018), Paulomi Chakraborty questions the binary to discuss the figure of the 'refugee woman' in West Bengal.

xi Manoranjan Mondal interviewed by the author on 15 March 2017
} 
xii Sukhen Howladar (name changed, pseudonym reference ZZ6XW1) interviewed by Raikamal Roy on 12 October 2014, The 1947 Partition Archive and Tata Trust. Web. Accessed on 30 May 2021 [https://in.1947partitionarchive.org/story/1222]

xiii Santi Ranjan Banerjee interviewed by the author on 18 March 2021

xiv Debabrata Dutta interviewed by the author on 8 February 2020

${ }^{x v}$ Pabitra Bhushan Bhattacharya interviewed by the author on 6 February 2020

xvi For a detailed analysis of the 'nationalising process' of a nation-state, see Roger Brubaker's 'National Minorities, Nationalizing States, and External National Homelands in the New Europe' in Nationalism Reframed, 1996, p. 55-76

xvii Prasanta Kumar Chatterjee interviewed by the author on 5 February 2020

xviii Mahesh Das (name changed, pseudonym reference TARCAJ) interviewed by Deborshi Chakraborty on 24 August 2015, The 1947 Partition Archive and Tata Trust. Web. Accessed on 31 May 2021 [https://in.1947partitionarchive.org/story/1878]

${ }^{x i x}$ Nilima Kundu interviewed by the author on 12 November 2018

${ }^{x x}$ Santosh Kumar Biswas interviewed by the author on 26 June 2018

\section{References}

Appadurai, A. (2006). Fear of Small Numbers: An Essay on the Geography of Anger. Duke University Press. Bandyopadhyay, H. (1960). Udbastu. Sahitya Sangsad.

Byapari, M. (2018). Interrogating My Chandal Life: An Autobiography of a Dalit (S. Mukherjee, Trans.). Sage. Chakraborty, P. (2018). The Refugee Woman: Partition of Bengal, Gender, and the Political. Oxford University Press.

Chatterji, J. (2019). The Fashioning of a Frontier: The Radcliffe Line and Bengal's Border Landscape 19471952. In Partition's Legacies (pp. 49-121). Permanent Black.

-----. (2007). The Spoils of Partition: Bengal and India, 1947-1967. Cambridge University Press.

Das, S. (2003). State Response to the Refugee Crisis: Relief and Rehabilitation in the East. In Refugees and the State: Practices of Asylum and Care in India, 1947-2000 (pp. 106-151). Sage.

Ferris, E., \& Kemal Kirișci. (2016). The Consequence of Chaos: Syria's Humanitarian Crisis and the Failure to Protect. The Brookings Institution Press.

Gellner, E. (1983). Nations and Nationalism. Basil Blackwell.

Gera Roy, A. (2020). Memories and Postmemories of the Partition of India. Routledge.

Ghoshal, A. (2021). Refugees, Borders and Identities: Rights and Habitat in East and Northeast India. Routledge.

Jain, S., \& Sarin, A. (Eds.). (2018). The Psychological Impact of the Partition of India. Sage.

Kabir, A. J. (2013). Partition's Post-Amnesias: 1947, 1971 and Contemporary South Asia. Women Unlimited.

Khan, Y. (2017). The Great Partition: The Making of India and Pakistan (2nd ed.). Yale University Press.

Krause, U., \& Schmidt, H. (2020). Refugees as Actors? Critical Reflections on Global Refugee Policies on Self-reliance and Resilience. Journal of Refugee Studies, 33(1), 22-41. https://doi.org/10.1093/jrs/fezo59

Mukhopadhyay, S. (2021). Memories of the 1947 Bengal Partition and Its Aftermath: Tanvir Mokammel's Seemantorekha. Studies in People's History, 8(1), 135-146. https://doi.org/10.1177/2348448921999039

-----. (2019). Thinking of Migration through Caste: Reading Oral Narratives of 'Displaced Person(s)' from East Pakistan (1950-1970). Journal of Migration Affairs, 2(1), 113-131.

https://doi.org/10.36931/jma.2019.2.1.113-131

Murshid, N. (2013). The Politics of Refugees in South Asia: Identity, Resistance, Manipulation. Routledge.

Na Li. (2020). History, Memory, and Identity: Oral History in China. The Oral History Review, 47(1), 26-51. https://doi.org/10.108o/oo940798.2020.1714452

Nandy, A. (2002). The Death of an Empire. In Bruised Memories: Communal Violence and The Writer (pp. 514). Seagull Books. 
Portelli, A. (2019). Living Voices: The Oral History Interview as Dialogue and Experience. The Oral History Review, 45(2), 239-248. https://doi.org/10.1093/ohr/ohyo3o

-----(1991). The Death of Luigi Trastulli and Other Stories: Form and Meaning in Oral History. State University of New York Press.

Ray, M. (2001). Growing Up Refugee: On Memory and Locality. India International Centre Quarterly, 28(2), 119-137.

Samaddar, R. (2003). Introduction- Power and care: Building the New Indian State. In Refugees and the State: Practices of Asylum and care in India 1947-200o (pp. 21-68). Sage.

Sarkar, B. (2010). Mourning the Nation: Indian Cinema in the Wake of Partition. Orient Blackswan.

Sen, U. (2018). Citizen Refugee: Forging the Indian Nation after Partition. Cambridge University Press.

White, H. (1984). The Question of Narrative in Contemporary Historical Theory. History and Theory, 23(1), $1-33$.

Wiesner, A. (2021). The Dialogic Process, Relational Approach, and Transformative Aspect of Interviewing. The Oral History Review, 48(1), 100-115. https://doi.org/10.108o/o0940798.2021.1894076

Zaidi, S. A. (1991). Sindhi vs Mohajir in Pakistan: Contradiction, Conflict, Compromise. Economic E Political Weekly, 26(20), 1295-1302.

Sumallya Mukhopadhyay is a Doctoral Fellow and Teaching Assistant in the Department of Humanities \& Social Sciences, Indian Institute of Technology Delhi, New Delhi. His area of interest includes, among other things, the politics of dispossession in narratives related to the 1947 Partition of Bengal. He has been awarded the International Oral History Association Scholarship (February 2020) and TATA Trusts - Partition Archive Research Grant (April 2021). His recent publications are forthcoming from Narrative Culture (Wayne State University Press, 2022) and Routledge Series on Migration (Routledge, 2022). 